\title{
Evaluation of TIAX High Energy CAM-7/Graphite Lithium- Ion Batteries at High and Low Temperatures
}

\author{
by Joshua L Allen, Jan L Allen, Samuel A Delp, and T Richard Jow
}

ARL-TR-7023

August 2014 


\section{NOTICES}

\section{Disclaimers}

The findings in this report are not to be construed as an official Department of the Army position unless so designated by other authorized documents.

Citation of manufacturer's or trade names does not constitute an official endorsement or approval of the use thereof.

Destroy this report when it is no longer needed. Do not return it to the originator. 


\title{
Army Research Laboratory
}

Adelphi, MD 20783-1138

ARL-TR-7023

August 2014

\section{Evaluation of TIAX High Energy CAM-7/Graphite Lithium- Ion Batteries at High and Low Temperatures}

\author{
Joshua L Allen, Jan L Allen, Samuel A Delp, and T Richard Jow \\ Sensors and Electron Devices Directorate, ARL
}




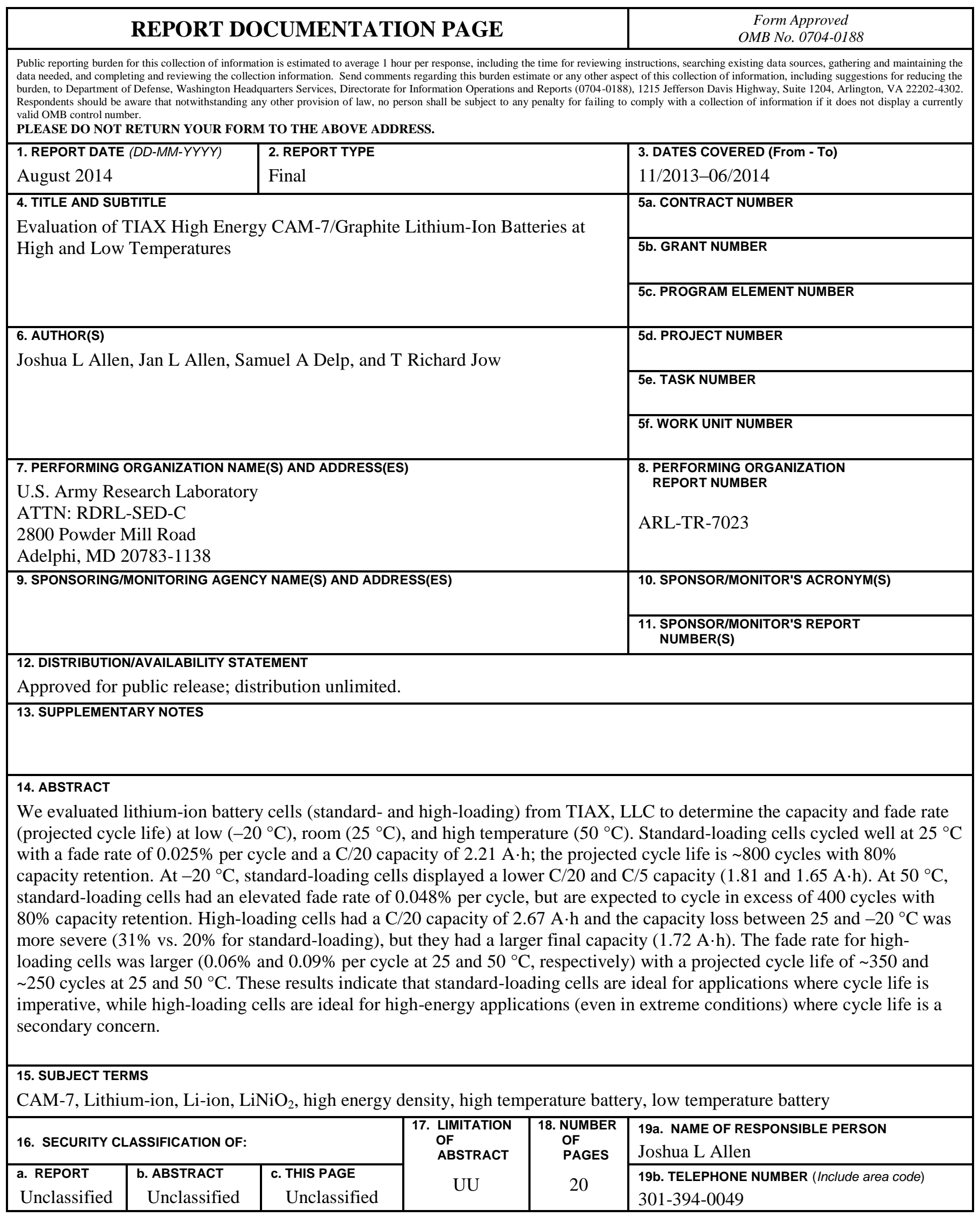




\section{Contents}

List of Figures $\quad$ iv

List of Tables $\quad$ iv

$\begin{array}{ll}\text { 1. Introduction } & 1\end{array}$

2. Approach 2

$\begin{array}{lr}\text { 3. Results } & 4\end{array}$

3.1 Standard-Loading Electrodes ......................................................................

3.2 High-Loading Electrodes With/Without Optimized Cell Hardware .............................

$\begin{array}{ll}\text { 4. Conclusions } & 10\end{array}$

$\begin{array}{ll}\text { List of Symbols, Abbreviations, and Acronyms } & 12\end{array}$

$\begin{array}{ll}\text { Distribution List } & 13\end{array}$ 


\section{List of Figures}

Fig. 1 Calculated specific energy (left) and energy density (right) of fixed volume 18650 cell designs with $5 \mathrm{~mA} \cdot \mathrm{h} \mathrm{cm}^{-2}$ active material loading. Data provided by TIAX.

Fig. 2 Voltage profile and specific capacity of cathode materials with a Li metal anode ( $\mathrm{C} / 20$ rate). Average discharge potential given in parentheses. Data provided by TIAX.

Fig. 3 Room temperature $\left(25^{\circ} \mathrm{C}\right.$, cycles $\left.1-20\right)$ and low temperature $\left(-20^{\circ} \mathrm{C}\right.$, cycles $\left.21-24\right)$ rate cycling and room temperature cycle life testing $\left(25^{\circ} \mathrm{C}\right.$, cycles $\left.25-127\right)$ of standardloading cells $(2.7-4.2 \mathrm{~V})$

Fig. 4 Room temperature $\left(25^{\circ} \mathrm{C}\right)$ differential capacity of 18650 cells with standard-loading electrodes. Cycles $1-100$ every 10 cycles shown.

Fig. 5 High temperature $\left(50{ }^{\circ} \mathrm{C}\right)$ cycle life testing $(2.7-4.1 \mathrm{~V}$; Charge: $\mathrm{C} / 2 \mathrm{CC}, \mathrm{CV}$ to $\mathrm{C} / 20$; Discharge: $\mathrm{C} / 5$ for $1^{\text {st }}$ and $102^{\text {nd }}$ cycle, $1 \mathrm{C}$ for $2^{\text {nd }}-101^{\text {st }}$ cycle)

Fig. 6 Room temperature $\left(25^{\circ} \mathrm{C}\right.$, cycles $\left.1-20\right)$ and low temperature $\left(-20{ }^{\circ} \mathrm{C}\right.$, cycles $\left.21-23\right)$ rate cycling of high energy 18650 cells .

Fig. 7 Room temperature $\left(25^{\circ} \mathrm{C}\right)$ cycle life testing (2.7-4.2 V; Charge: $\mathrm{C} / 5 \mathrm{CC}, \mathrm{CV}$ to $\mathrm{C} / 20$; Discharge: $\mathrm{C} / 10$ for $1^{\text {st }}$ and $52^{\text {nd }}$ cycle, $\mathrm{C} / 2$ for $2^{\text {nd }}-51^{\text {st }}$ cycle) of high energy 18650 cells

Fig. 8 High temperature $\left(50^{\circ} \mathrm{C}\right)$ cycle life testing $(2.7-4.1 \mathrm{~V}$; Charge: $\mathrm{C} / 5 \mathrm{CC}, \mathrm{CV}$ to $\mathrm{C} / 20$; Discharge: $\mathrm{C} / 10$ for $1^{\text {st }}$ and $52^{\text {nd }}$ cycle, $\mathrm{C} / 2$ for $2^{\text {nd }}-51^{\text {st }}$ cycle) of high energy cells

\section{List of Tables}

Table 1 Battery specifications and description of testing performed ..... 3

Table 2 Description of testing procedures used to evaluate cell performance 3

Table 3 Capacity and specific energy of standard- and high-loading cells at $25{ }^{\circ} \mathrm{C}$ and $-20^{\circ} \mathrm{C}$ with discharge rates of $\mathrm{C} / 20, \mathrm{C} / 10, \mathrm{C} / 5, \mathrm{C} / 2$, and $1 \mathrm{C}$. .8 


\section{Introduction}

The objective of this effort is to evaluate prototype lithium (Li)-ion battery cells provided by TIAX LLC in November 2013 for high and low temperature cycleability in accordance with the requirements set forth in Phase II of the Small Business Innovation Research (SBIR) program, solicitation topic code OSD09-EP5 (contract number W911QX-12-C-0001).

Commercial Li-ion batteries are readily available with a specific energy in excess of $200 \mathrm{~W} \cdot \mathrm{h} / \mathrm{kg}$. Such batteries are based upon cathode chemistries that typically include lithium cobalt oxide $\left(\mathrm{LiCoO}_{2}\right.$ or $\left.\mathrm{LCO}\right)$ and lithium nickel cobalt aluminum oxide $\left(\mathrm{LiNi}_{\mathrm{x}} \mathrm{Co}_{\mathrm{y}} \mathrm{Al}_{\mathrm{z}} \mathrm{O}_{2}\right.$ or NCA). The commercialization of Li-ion battery cells in excess of $200 \mathrm{~W} \cdot \mathrm{h} / \mathrm{kg}$ has enabled the development of next-generation plug-in hybrid electric vehicles (PHEVs), hybrid electric vehicles (HEVs), and fully electric vehicles (EVs), and has provided power improvements to consumer electronics. Although the military requirements for Li-ion battery specifications are very similar to those used in EVs or consumer electronics (i.e., greater specific energy [W.h/kg] and energy density $[\mathrm{W} \cdot \mathrm{h} / \mathrm{L}])$, there are some notable challenges associated with the military implementation of commercial "state-of-the-art" Li-ion batteries.

Batteries used in military applications must be lightweight, compact rechargeable batteries that are capable of operating over a wide temperature range. A critical limitation of commercial Liion batteries is their poor low temperature performance $\left(<-20{ }^{\circ} \mathrm{C}\right)$, due to decreased ionic conductivity, and instability at higher temperatures $\left(>50^{\circ} \mathrm{C}\right)$, due to the degradation of the electrolyte, dissolution of the cathode active materials in the electrolyte, and/or breakdown of the cathode materials resulting in steady performance degradation including capacity fade and impedance rise in the cells.

The prototype cells provided by TIAX LLC in November 2013 include their patented layeredstructure dopant-stabilized lithium nickel oxide $\left(\mathrm{LiNiO}_{2}\right.$ or $\left.\mathrm{LNO}\right)$ cathode, referred to as CAM$7^{\mathrm{TM}}$ by TIAX, a graphitic anode, and a proprietary electrolyte. When compared with commercially available cathode materials, including lithium manganese oxide $\left(\mathrm{LiMn}_{2} \mathrm{O}_{4}\right.$ or LMO), lithium iron phosphate $\left(\mathrm{LiFePO}_{4}\right.$ or LFP), lithium nickel cobalt manganese oxide $\left(\mathrm{LiNi}_{\mathrm{x}} \mathrm{Co}_{\mathrm{y}} \mathrm{Mn}_{\mathrm{z}} \mathrm{O}_{2}\right.$ or NCM), LCO, and NCA, CAM-7 based 18650 cells have a higher specific energy and energy density (Fig. 1). The low end-of charge potential for CAM-7 (4.3 V vs. Li compared to $>4.8 \mathrm{~V}$ for high voltage materials such as lithium nickel manganese oxide [ $\mathrm{LiNi}_{0.5} \mathrm{Mn}_{1.5} \mathrm{O}_{4}$ or $\left.\mathrm{LNMO}\right]$ and lithium cobalt phosphate $\left[\mathrm{LiCoPO}_{4}\right.$ or $\left.\mathrm{LCP}\right]$ ) is beneficial for reducing the irreversible oxidation of the electrolyte and thus enables a long-cycle life. The higher specific capacity of CAM-7 yields an impressive specific energy when compared with the state-of-the art cathodes (Fig. 2). The room temperature performance of the CAM-7/graphite system has been well studied and compared with similar cathode materials. This report evaluates 
the high and low temperature performance of CAM-7/graphite 18650 cells to determine if they are suitable for extreme environmental conditions.
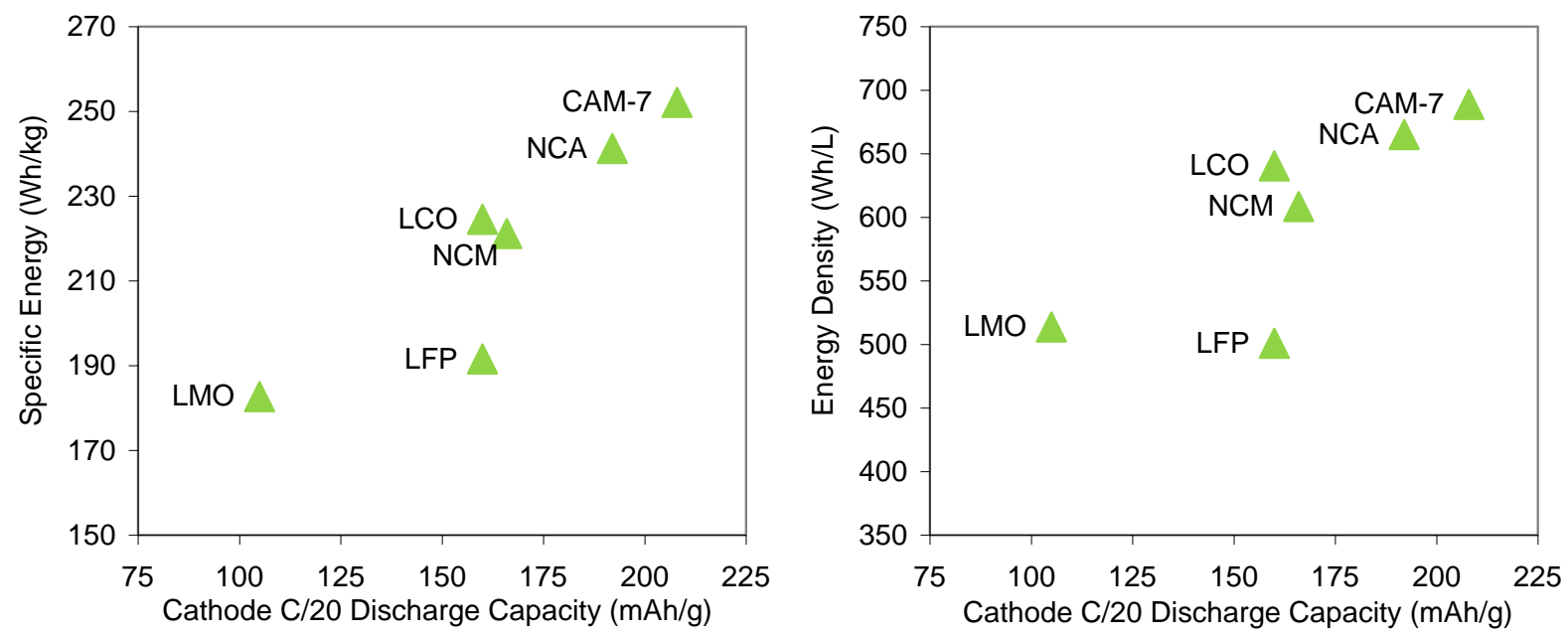

Fig. 1 Calculated specific energy (left) and energy density (right) of fixed volume 18650 cell designs with $5 \mathrm{~mA} \cdot \mathrm{h} \mathrm{cm}^{-2}$ active material loading. Data provided by TIAX

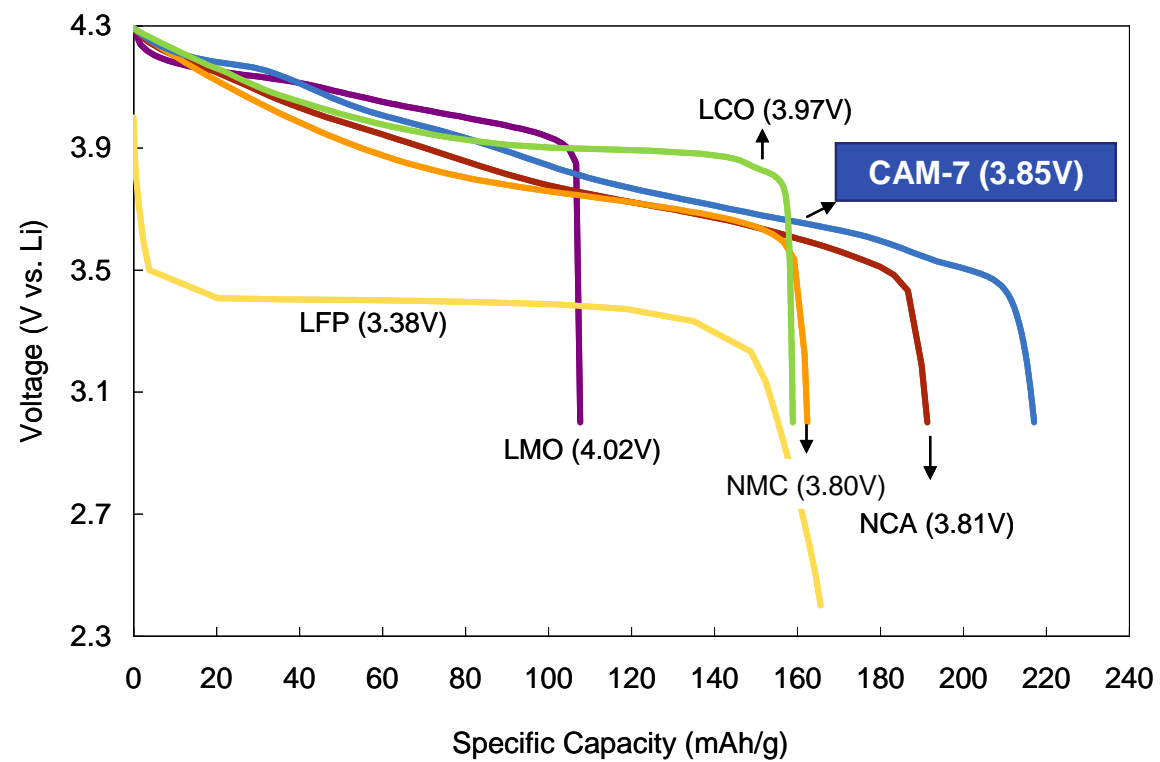

Fig. 2 Voltage profile and specific capacity of cathode materials with a Li metal anode $(\mathrm{C} / 20$ rate). Average discharge potential given in parentheses. Data provided by TIAX.

\section{Approach}

CAM-7 based 18650 cells were provided by TIAX LLC in two batches. Batch 1 (JA428-JA431) consists of four cells (two sets of duplicate cells) with standard-loading electrodes, carbonate- 
based electrolyte, and a high porosity separator. Batch 2 (JA402-JA407) consists of six cells (three sets of duplicate cells) with high density and high active material loading electrodes, a carbonate-based electrolyte, and a high porosity separator. Cells JA402 and JA403 also contain an engineered 18650 hardware that improves the specific energy by reducing the weight of the inert materials. The specifications of the prototype Li-ion cells are provided in Table 1 . The testing procedures for evaluating the cell performance are provided in Table 2.

Table 1 Battery specifications and description of testing performed

\begin{tabular}{|c|c|c|c|}
\hline Cell ID & $\mathbf{C / 2 0}(\mathbf{A} \cdot \mathbf{h} / \mathbf{W} \cdot \mathbf{h})$ & Cell Weight $\mathbf{( g )}$ & Test Description \\
\hline JA428 & $2.2 / 8.1$ & 40.36 & \multirow{2}{*}{ RT rate, LT Capacity, RT Cycle Life } \\
JA429 & $2.2 / 8.3$ & 40.57 & HT Cycle Life \\
\hline JA430 & $2.2 / 8.2$ & 40.33 & \multirow{2}{*}{ RT Rate, LT Capacity } \\
JA431 & $2.1 / 7.9$ & 40.38 & \multirow{2}{*}{ RT Cycle Life } \\
\hline JA402 & $2.7 / 10.0$ & 40.28 & \multirow{2}{*}{ HT Cycle Life } \\
\hline JA403 & $2.7 / 10.0$ & 42.42 & \\
\hline JA404 & $2.7 / 9.9$ & 42.33 & 42.25 \\
\hline JA405 & $2.7 / 9.9$ & 42.39 & \\
\hline JA406 & $2.7 / 10.0$ & $2.7 / 10.0$ &
\end{tabular}

Table 2 Description of testing procedures used to evaluate cell performance

\begin{tabular}{|c|c|}
\hline Cell ID & Testing Procedures \\
\hline $\begin{array}{l}\text { JA428 } \\
\text { JA429 }\end{array}$ & $\begin{array}{l}\text { RT Rate }\left(25{ }^{\circ} \mathrm{C}\right) \\
\text { - Charge: } \mathrm{C} / 2 \mathrm{CC} \text { to } 4.2 \mathrm{~V}, \mathrm{CV} \text { with } \mathrm{C} / 20 \text { cutoff } \\
\text { - Discharge: to } 2.7 \mathrm{~V} \text { at } \mathrm{C} / 20, \mathrm{C} / 10, \mathrm{C} / 2 \text { and } 1 \mathrm{C} \\
\text { LT Capacity }\left(-20^{\circ} \mathrm{C}\right) \\
\text { - Charge }(\text { at } \mathrm{RT}): \mathrm{C} / 2 \mathrm{CC} \text { to } 4.2 \mathrm{~V}, \mathrm{CV} \text { with } \mathrm{C} / 20 \text { cutoff } \\
\text { - Discharge (at } \mathrm{LT}): \text { to } 2.7 \mathrm{~V} \text { at } \mathrm{C} / 20, \mathrm{C} / 10, \mathrm{C} / 5 \text { and } \mathrm{C} / 2 \\
R T C y c l e \text { Life }\left(25^{\circ} \mathrm{C}\right) \\
\text { - Charge: } \mathrm{C} / 2 \mathrm{CC} \text { to } 4.2 \mathrm{~V}, \mathrm{CV} \text { with } \mathrm{C} / 20 \text { cutoff } \\
\text { - Discharge: to } 2.7 \mathrm{~V} \text { at } \mathrm{C} / 51^{\text {st }} \text { and last cycle } \\
\text { - Discharge: to } 2.7 \mathrm{~V} \text { at } 1 \mathrm{C} \times 100 \text { cycles }\end{array}$ \\
\hline $\begin{array}{l}\text { JA430 } \\
\text { JA431 }\end{array}$ & $\begin{array}{l}\text { HT Cycle Life }\left(50^{\circ} \mathrm{C}\right) \\
\text { - Charge: } \mathrm{C} / 2 \mathrm{CC} \text { to } 4.1 \mathrm{~V}, \mathrm{CV} \text { with } \mathrm{C} / 20 \text { cutoff } \\
\text { - Discharge: to } 2.7 \mathrm{~V} \text { at } \mathrm{C} / 51^{\text {st }} \text { and last cycle } \\
\text { - } \quad \text { Discharge: to } 2.7 \mathrm{~V} \text { at } 1 \mathrm{C} \times 100 \text { cycles }\end{array}$ \\
\hline $\begin{array}{l}\text { JA402 } \\
\text { JA403 } \\
\text { Improved } \\
\text { Hardware }\end{array}$ & $\begin{array}{l}\text { RT Rate }\left(25^{\circ} \mathrm{C}\right) \\
\text { - Charge: } \mathrm{C} / 5 \mathrm{CC} \text { to } 4.2 \mathrm{~V}, \mathrm{CV} \text { with } \mathrm{C} / 20 \text { cutoff } \\
\text { - Discharge: to } 2.7 \mathrm{~V} \text { at } \mathrm{C} / 20, \mathrm{C} / 10, \mathrm{C} / 5 \text { and } \mathrm{C} / 2 \\
\text { LT Capacity }\left(-20^{\circ} \mathrm{C}\right) \\
\text { - Charge (at RT): } \mathrm{C} / 5 \mathrm{CC} \text { to } 4.2 \mathrm{~V}, \mathrm{CV} \text { with } \mathrm{C} / 20 \text { cutoff } \\
\text { - Discharge (at LT): to } 2.7 \mathrm{~V} \text { at } \mathrm{C} / 20, \mathrm{C} / 10 \text { and } \mathrm{C} / 5 \\
\end{array}$ \\
\hline $\begin{array}{l}\text { JA404 } \\
\text { JA405 }\end{array}$ & $\begin{array}{l}\text { RT Cycle Life }\left(25^{\circ} \mathrm{C}\right) \\
\text { - Charge: } \mathrm{C} / 5 \mathrm{CC} \text { to } 4.2 \mathrm{~V}, \mathrm{CV} \text { with } \mathrm{C} / 20 \text { cutoff } \\
\text { - Discharge: to } 2.7 \mathrm{~V} \text { at } \mathrm{C} / 101^{\text {st }} \text { and last cycle } \\
\text { - Discharge: to } 2.7 \mathrm{~V} \text { at } \mathrm{C} / 2 \times 50 \text { cycles }\end{array}$ \\
\hline $\begin{array}{l}\text { JA406 } \\
\text { JA407 }\end{array}$ & $\begin{array}{l}\text { HT Cycle Life }\left(50^{\circ} \mathrm{C}\right) \\
\text { - Charge: } \mathrm{C} / 5 \mathrm{CC} \text { to } 4.1 \mathrm{~V}, \mathrm{CV} \text { with } \mathrm{C} / 20 \text { cutoff } \\
\text { - Discharge: to } 2.7 \mathrm{~V} \text { at } \mathrm{C} / 101^{\text {st }} \text { and last cycle } \\
\text { - Discharge: to } 2.7 \mathrm{~V} \text { at } 1 \mathrm{C} \times 50 \text { cycles }\end{array}$ \\
\hline
\end{tabular}

Note: $\mathrm{HT}=$ high temperature, $\mathrm{LT}=$ low temperature, and $\mathrm{RT}=$ room temperature 


\section{Results}

\subsection{Standard-Loading Electrodes}

The first batch of 18650 cells provided by TIAX LLC consisted of standard-loading electrodes with a carbonate-based electrolyte. The variable rate testing (Fig. 3) yielded a cell discharge capacity of $2.23,2.12,2.03$, and $1.97 \mathrm{~A} \cdot \mathrm{h}$ at a discharge rate of $\mathrm{C} / 20, \mathrm{C} / 5, \mathrm{C} / 2$, and $1 \mathrm{C}$, respectively. The corresponding specific energies of these cells were 203, 191, 181, and $172 \mathrm{~W} \cdot \mathrm{h} / \mathrm{kg}$ at discharge rates of $\mathrm{C} / 20, \mathrm{C} / 5, \mathrm{C} / 2$, and $1 \mathrm{C}$, respectively. To test the low temperature performance, the cells were charged at room temperature $(\mathrm{CCCV}$ at $\mathrm{C} / 2$ with $\mathrm{C} / 20$ cutoff) and transferred to an environmental chamber that was maintained at $-20{ }^{\circ} \mathrm{C}$. The cells were allowed to equilibrate for $1 \mathrm{~h}$ and discharged at various rates. The cell discharge capacity obtained was $1.83,1.76,1.66$, and $1.39 \mathrm{~A} \cdot \mathrm{h}$ for discharge rates of $\mathrm{C} / 20, \mathrm{C} / 10, \mathrm{C} / 5$, and $\mathrm{C} / 2$, respectively (Fig. 3). After testing the room temperature and low temperature rate performance of the cells, the room temperature cycle life was tested to see if the variable rate or low temperature had any effect on the cell cycleability. A single $\mathrm{C} / 5$ cycle was performed to verify the capacity is consistent with the cycles performed during the room temperature rate testing; the cells actually displayed a higher $\mathrm{C} / 5$ capacity of $2.12 \mathrm{~A} \cdot \mathrm{h}$, compared with the $2.09 \mathrm{~A} \cdot \mathrm{h}$ capacity previously obtained. The cycle life of the cell was tested by performing 100 cycles at $1 \mathrm{C}$ and finally testing the $\mathrm{C} / 5$ capacity again to compare with the previous results. The $1 \mathrm{C}$ capacity of the cells decayed from 1.99 to $1.94 \mathrm{~A} \cdot \mathrm{h}$ after 100 cycles, a fade rate of $2.5 \%$ over 100 cycles or $\sim 0.025 \%$ per cycle. This indicates the system projects to be capable of $\sim 800$ cycles while still maintaining $80 \%$ of the original capacity. The final $\mathrm{C} / 5$ cycle is consistent with the previous results with a fade rate of $\sim 2.4 \%$ after 100 cycles $(2.01 \mathrm{~A} \cdot \mathrm{h}$ for the final $\mathrm{C} / 5$ cycle). 


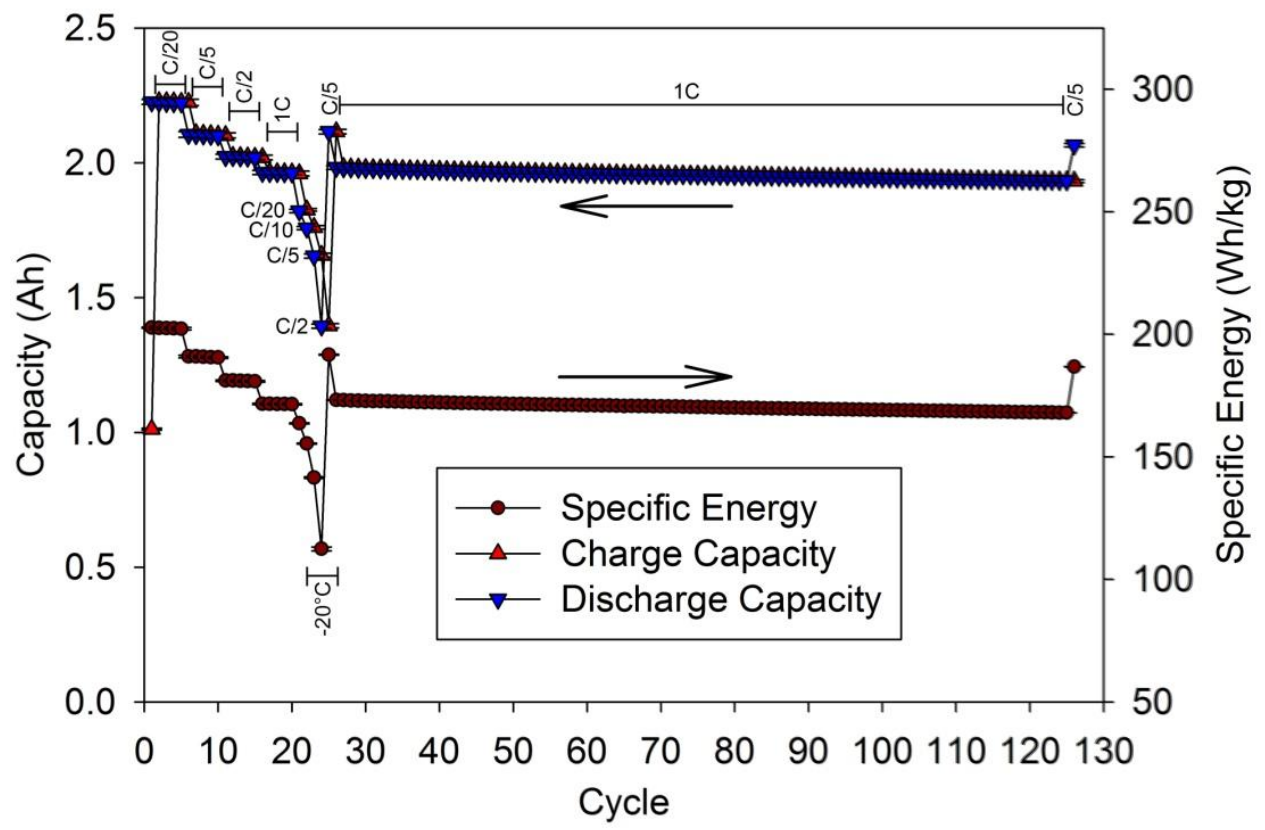

Fig. 3 Room temperature $\left(25^{\circ} \mathrm{C}\right.$, cycles $\left.1-20\right)$ and low temperature $\left(-20^{\circ} \mathrm{C}\right.$, cycles $\left.21-24\right)$ rate cycling and room temperature cycle life testing $\left(25^{\circ} \mathrm{C}\right.$, cycles $\left.25-127\right)$ of standard-loading cells $(2.7-4.2 \mathrm{~V})$

To better demonstrate the electrode material's stability, the differential capacity of the room temperature cycle life test was plotted as a function of the full cell voltage. The data in Fig. 4 are highly consistent through the 100 cycles with the only change between the individual cycles being a slight decrease in the reduction peak at $3.9 \mathrm{~V}$. The loss in capacity observed at $3.9 \mathrm{~V}$ is likely the cause of the $0.025 \%$ per cycle fade rate and may be due to slight structural changes within the cathode material or loss of cycleable lithium to side reactions at the anode. It is noteworthy that no polarization was observed in Fig. 4, suggesting that stable passivation layers were formed and perpetual electrolyte decomposition did not occur (which would lead to impedance build-up and cell polarization). 


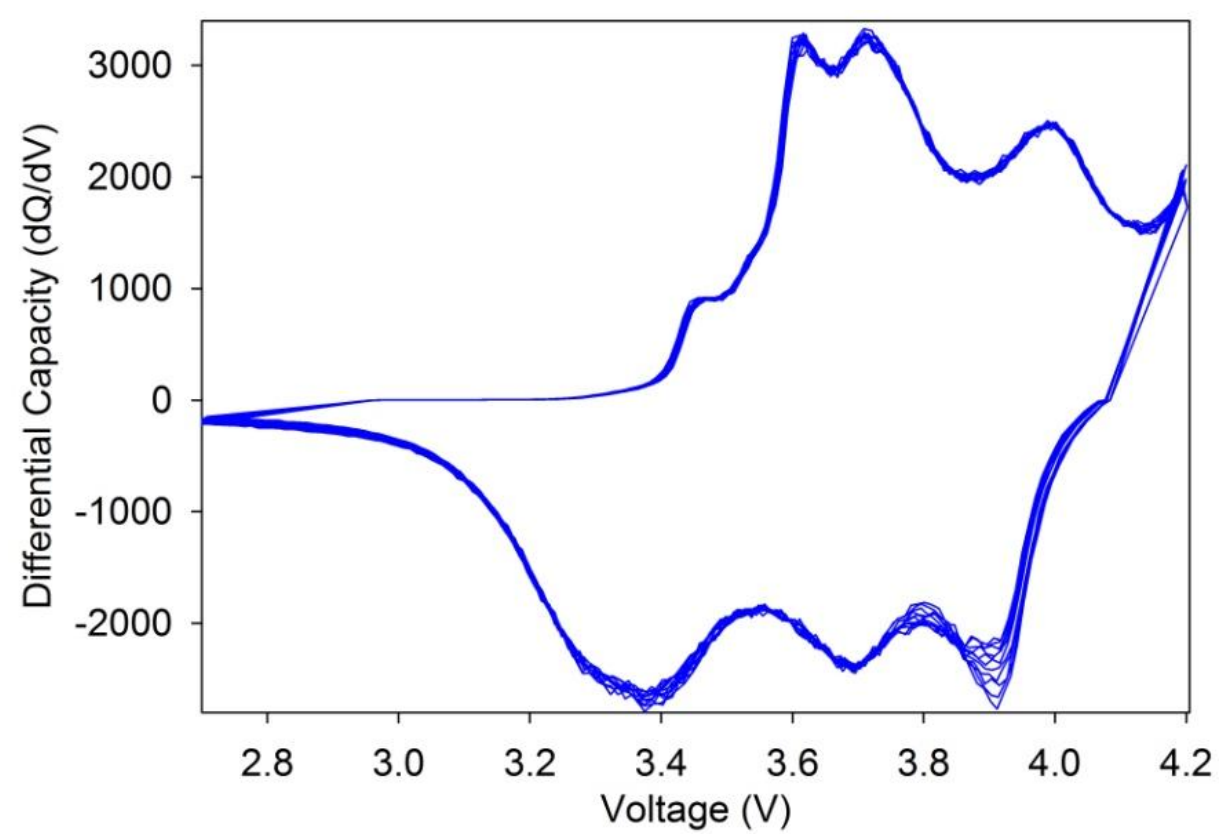

Fig. 4 Room temperature $\left(25^{\circ} \mathrm{C}\right)$ differential capacity of 18650 cells with standard-loading electrodes. Cycles $1-100$ every 10 cycles shown.

The second set of cells was tested at high temperature $\left(50{ }^{\circ} \mathrm{C}\right)$. High temperature testing is commonly used to demonstrate the cell's overall stability to high temperature (electrolyte decomposition kinetics increase with temperature) as well as to accelerate the life cycle of the cell. The high temperature testing of cells JA430-JA431 can be seen in Fig. 5. The cells were cycled at $\mathrm{C} / 5$ for the first and last cycle with 100 cycles of $\mathrm{C} / 2$ charge and $1 \mathrm{C}$ discharge in between. Although the cells were similar in design and content, cell JA431 displayed a lower capacity (see Table 1). Due to the differing capacity, and the fact that both cells were cycled at the same rate (2A discharge), the efficiency of the cells varied with the lower capacity cell (JA431) having a lower efficiency due to the higher discharge rate (1.05C for JA431 vs. 1.1C for JA430). The average capacity and efficiency is plotted in Fig. 5 with error bars demonstrating the high-low values. The average cell capacity of the first $1 \mathrm{C}$ cycle is $1.98 \pm 0.02 \mathrm{~A} \cdot \mathrm{h}$. After 100 cycles at $1 \mathrm{C}$, the cell average fades to $1.90 \pm 0.01 \mathrm{~A} \cdot \mathrm{h}$, suggesting the cell fades at a rate of $\sim 4.8 \%$ total through 100 cycles, or at a rate of $0.048 \%$ per cycle. Although the fade rate of $0.048 \%$ per cycle is roughly double the fade rate at room temperature $(0.025 \%$ per cycle), the cells still project to be able to cycle $\sim 400$ cycles until the capacity fades to $80 \%$ of the initial average capacity $(\sim 1.58 \mathrm{~A} \cdot \mathrm{h})$. 


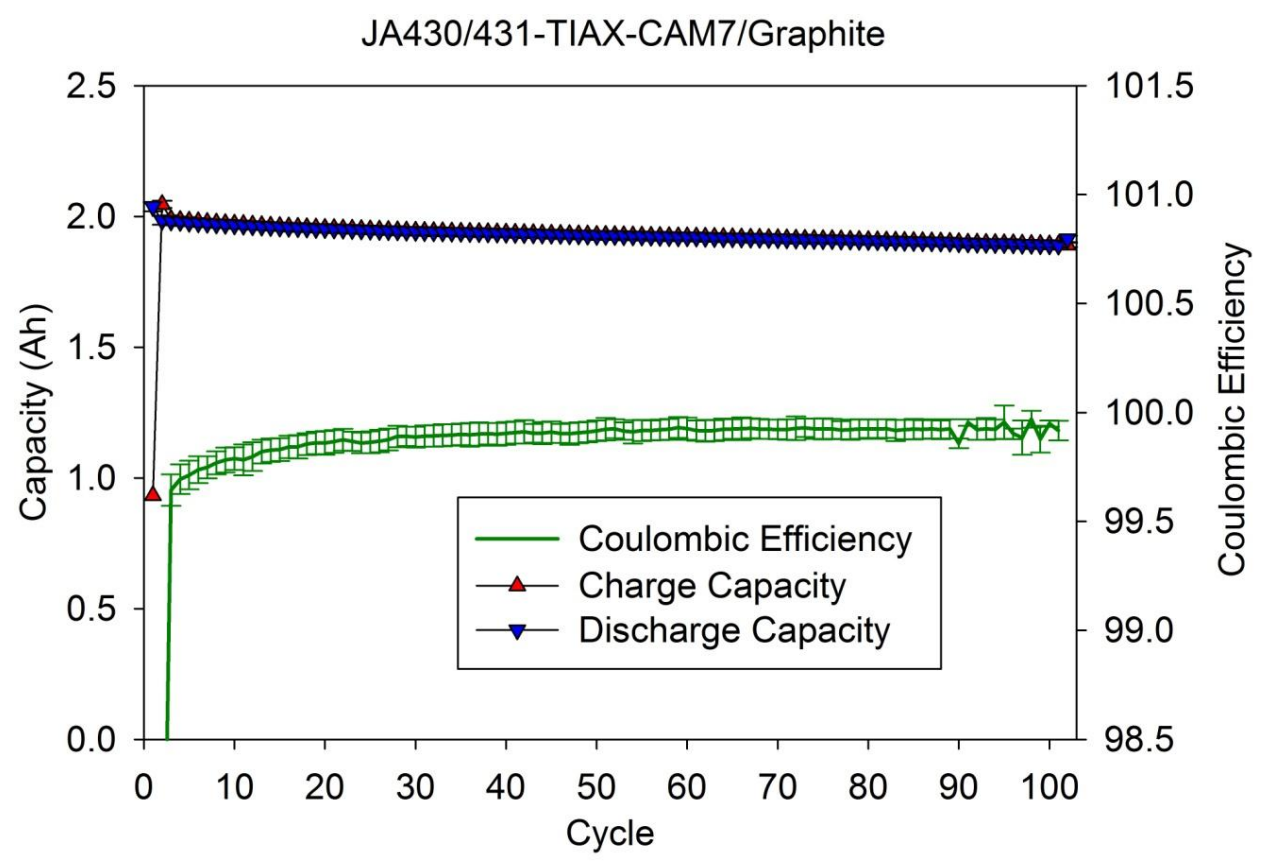

Fig. 5 High temperature $\left(50^{\circ} \mathrm{C}\right)$ cycle life testing $(2.7-4.1 \mathrm{~V}$; Charge: $\mathrm{C} / 2 \mathrm{CC}, \mathrm{CV}$ to $\mathrm{C} / 20$; Discharge: $\mathrm{C} / 5$ for $1^{\text {st }}$ and $102^{\text {nd }}$ cycle, $1 \mathrm{C}$ for $2^{\text {nd }}-101^{\text {st }}$ cycle)

\subsection{High-Loading Electrodes With/Without Optimized Cell Hardware}

Three sets of duplicate cells were provided by TIAX LLC with high-loading electrodes. The first set of cells (JA402-JA403) included an engineered hardware that improved the overall specific energy. Room temperature and low temperature variable rate testing was performed on the cells and the results are shown in Fig. 6. The cell capacities at room temperature are 2.67, 2.59, 2.51, and $2.36 \mathrm{~A} \cdot \mathrm{h}$ for discharge rates of $\mathrm{C} / 20, \mathrm{C} / 10, \mathrm{C} / 5$, and $\mathrm{C} / 2$, respectively. When the cell was reduced to $-20{ }^{\circ} \mathrm{C}$, the cell discharge capacity was reduced to $2.14,2.02$, and $1.72 \mathrm{~A} \cdot \mathrm{h}$ for discharge rates of $\mathrm{C} / 20, \mathrm{C} / 10$, and $\mathrm{C} / 5$, respectively. The specific energies of the improved hardware cells at $25^{\circ} \mathrm{C}$ were $240,232,221$, and $201 \mathrm{~W} \cdot \mathrm{h} / \mathrm{kg}$ at discharge rates of C/20, C/10 C/5 and $\mathrm{C} / 2$, respectively. At low temperature $\left(-20^{\circ} \mathrm{C}\right)$, the specific energy drops to 189,174 , and $144 \mathrm{~W} \cdot \mathrm{h} / \mathrm{kg}$ for $\mathrm{C} / 20, \mathrm{C} / 10$, and $\mathrm{C} / 5$, respectively. A comparison of the variable rate capacity and specific energy at $25^{\circ} \mathrm{C}$ and $-20^{\circ} \mathrm{C}$ of the standard- and high-loading cells is shown in Table 3. 


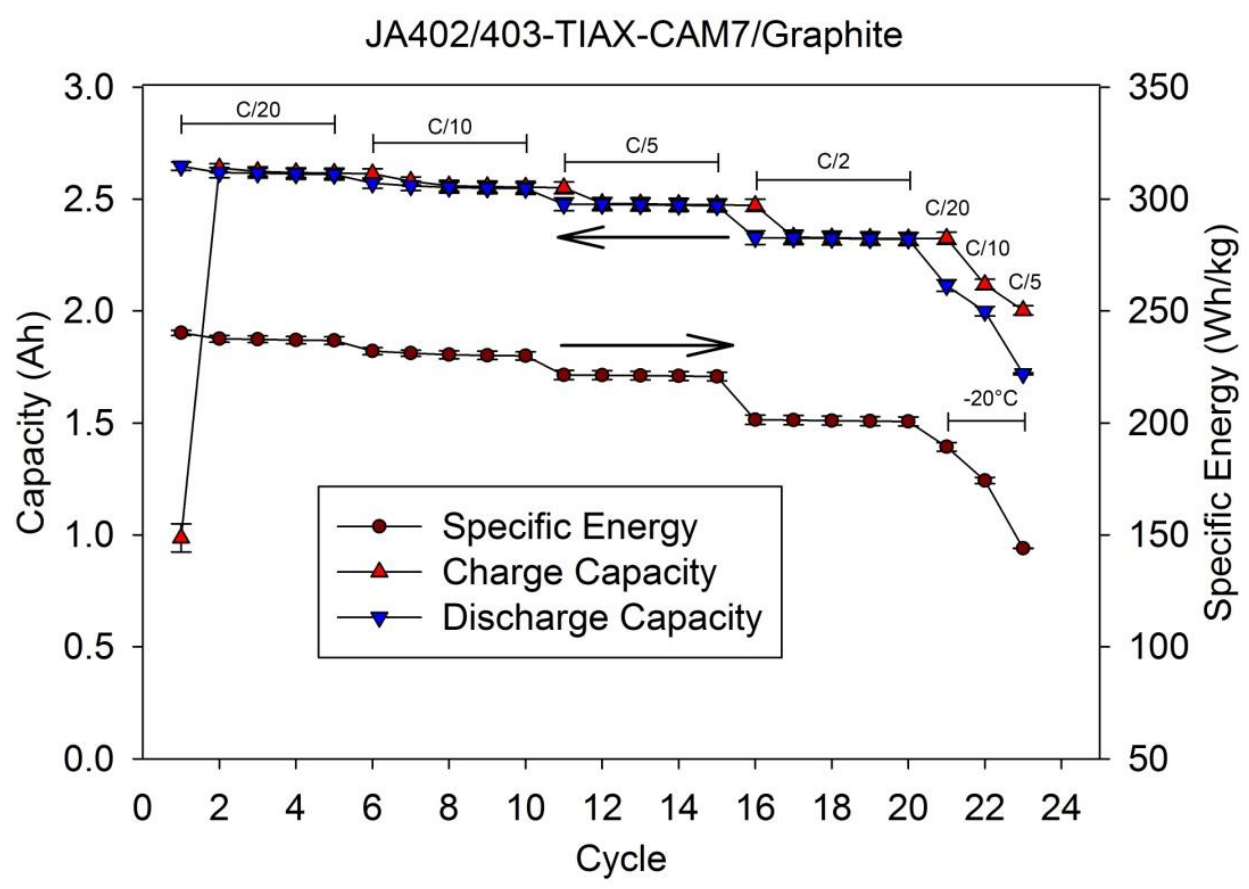

Fig. 6 Room temperature $\left(25^{\circ} \mathrm{C}\right.$, cycles $\left.1-20\right)$ and low temperature $\left(-20^{\circ} \mathrm{C}\right.$, cycles $\left.21-23\right)$ rate cycling of high energy 18650 cells

Table 3 Capacity and specific energy of standard- and high-loading cells at $25{ }^{\circ} \mathrm{C}$ and $-20{ }^{\circ} \mathrm{C}$ with discharge rates of $\mathrm{C} / 20, \mathrm{C} / 10, \mathrm{C} / 5, \mathrm{C} / 2$, and $1 \mathrm{C}$

\begin{tabular}{|c|c|c|c|c|c|c|c|c|c|c|c|}
\hline \multirow[b]{4}{*}{ Capacity $(\mathrm{A} \cdot \mathrm{h})$} & & \multicolumn{5}{|c|}{ JA428/429 Standard-Loading } & \multicolumn{5}{|c|}{ JA420/403 High-Loading } \\
\hline & & $\mathrm{C} / 20$ & $\mathrm{C} / \mathbf{1 0}$ & $\mathrm{C} / 5$ & $\mathrm{C} / 2$ & $1 \mathrm{C}$ & $\mathrm{C} / 20$ & $\mathrm{C} / \mathbf{1 0}$ & $\mathrm{C} / 5$ & $\mathrm{C} / 2$ & $1 \mathrm{C}$ \\
\hline & $25^{\circ} \mathrm{C}$ & 2.23 & - & 2.12 & 2.03 & 1.97 & 2.67 & 2.59 & 2.51 & 2.36 & - \\
\hline & $-20^{\circ} \mathrm{C}$ & 1.83 & 1.76 & 1.66 & 1.39 & - & 2.14 & 2.02 & 1.72 & - & - \\
\hline p & $25^{\circ} \mathrm{C}$ & 203 & - & 191 & 181 & 172 & 240 & 232 & 221 & 201 & - \\
\hline$(\mathrm{W} \cdot \mathrm{h} / \mathrm{kg})$ & $-20^{\circ} \mathrm{C}$ & 164 & 155 & 142 & 112 & - & 189 & 174 & 144 & - & - \\
\hline
\end{tabular}

The second pair of cells (JA404-JA405) was tested at room temperature for cycle life. Since these cells contained high-loading, thicker and shorter electrodes, the transport of $\mathrm{Li}^{+}$ions through the electrodes and the separator is hindered and thus the rate performance is reduced. If one compares the $\mathrm{C} / 20$ and $\mathrm{C} / 2$ capacity from Fig. 3 (1.81 and $1.65 \mathrm{~A} \cdot \mathrm{h}$, respectively) with the $\mathrm{C} / 20$ and $\mathrm{C} / 2$ capacity from Fig. 6 (2.67 and $2.36 \mathrm{~A} \cdot \mathrm{h}$, respectively), the capacity decline when increasing the rate from $\mathrm{C} / 20$ to $\mathrm{C} / 2$ is $\sim 8.8 \%$ with the standard-loading cells compared to $11.6 \%$ for the high-loading cells. Since the high-loading electrodes have diminished $\mathrm{Li}^{+}$ion transport, the cells are less able to delithiate fully at the point when the cell reaches the end voltage (i.e., the cell becomes polarized due to the slower kinetics). Due to the polarization phenomenon, the high-loading cells display a higher fade rate compared with the standard-loading cells. The cycle life of the high-loading cells is shown in Fig. 7. The capacity of the cells fades from an initial capacity $(\mathrm{C} / 2)$ of $2.40 \mathrm{~A} \cdot \mathrm{h}$ to a final capacity of $2.32 \mathrm{~A} \cdot \mathrm{h}$ (after 50 cycles). The fade rate of the cells is $\sim 3.3 \%$ over the 50 cycles or $0.06 \%$ per cycle. With an initial capacity of $2.40 \mathrm{~A} \cdot \mathrm{h}$ and a 
fade rate of $0.06 \%$ per cycle, the high-loading cells project to be able to be cycled $\sim 350$ cycles and still maintain $80 \%$ capacity retention $(\sim 1.92 \mathrm{~A} \cdot \mathrm{h})$.

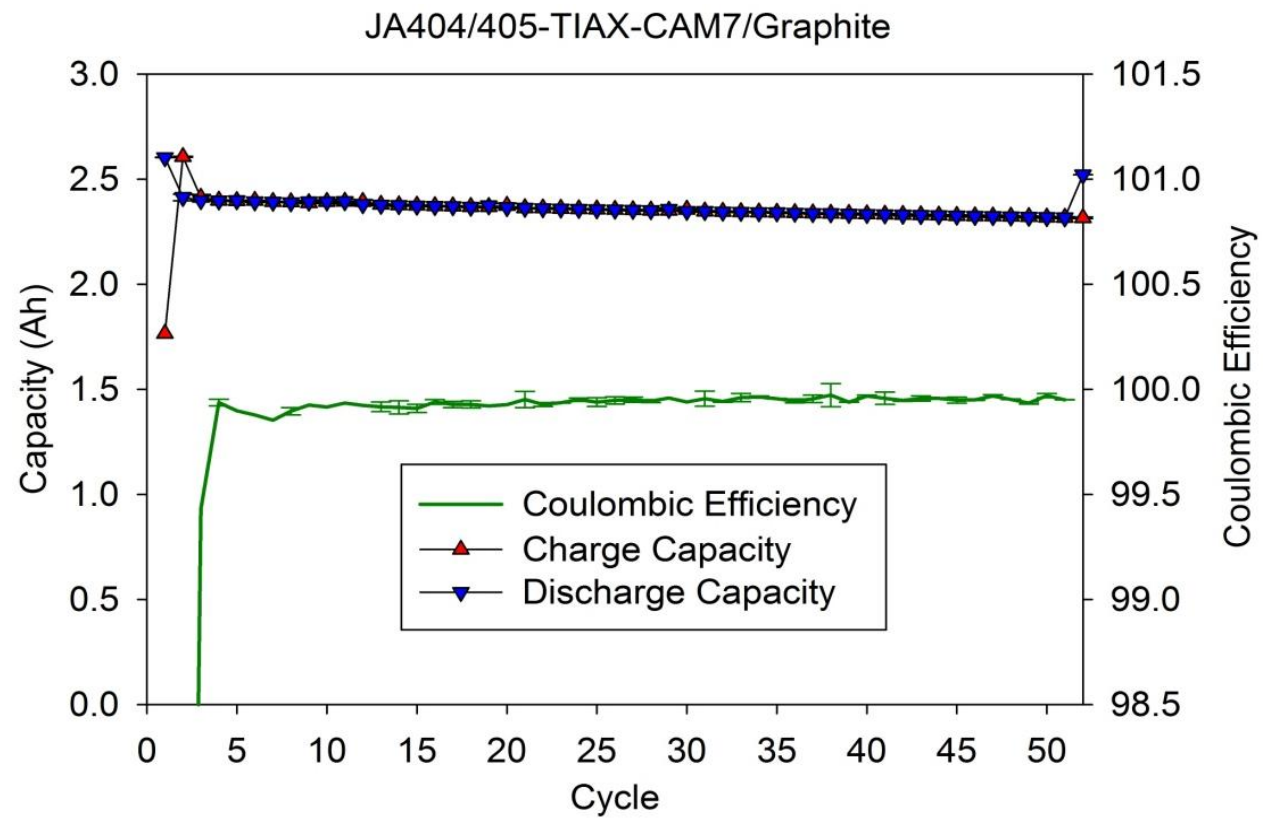

Fig. 7 Room temperature $\left(25^{\circ} \mathrm{C}\right)$ cycle life testing $(2.7-4.2 \mathrm{~V}$; Charge: $\mathrm{C} / 5 \mathrm{CC}, \mathrm{CV}$ to $\mathrm{C} / 20$; Discharge: $\mathrm{C} / 10$ for $1^{\text {st }}$ and $52^{\text {nd }}$ cycle, $\mathrm{C} / 2$ for $2^{\text {nd }}-51^{\text {st }}$ cycle) of high energy 18650 cells

The high-loading cells were also tested for high temperature stability (JA406-JA407). The high temperature cycle life results can be seen in Fig. 8. The high temperature cells $\left(50{ }^{\circ} \mathrm{C}\right)$ were cycled with a lower upper charging limit $(4.1 \mathrm{~V}$ vs. $4.2 \mathrm{~V}$ for the room temperature cycle life testing) in order to limit electrolyte oxidation and therefore display a lower overall capacity when compared to the room temperature tests. The initial capacity $(C / 2)$ of the high temperature cells was $2.34 \mathrm{~A} \cdot \mathrm{h}$. After 50 cycles, the cells faded $\sim 4.7 \%$ to a final capacity of $2.23 \mathrm{~A} \cdot \mathrm{h}$; the fade rate was $\sim 0.09 \%$ per cycle. Based on the initial capacity of $2.34 \mathrm{~A} \cdot \mathrm{h}$ and a fade rate of $0.09 \%$ per cycle, the high-loading cells project to be capable of being cycled $\sim 250$ cycles and still maintain $80 \%$ capacity retention at $50{ }^{\circ} \mathrm{C}$. 


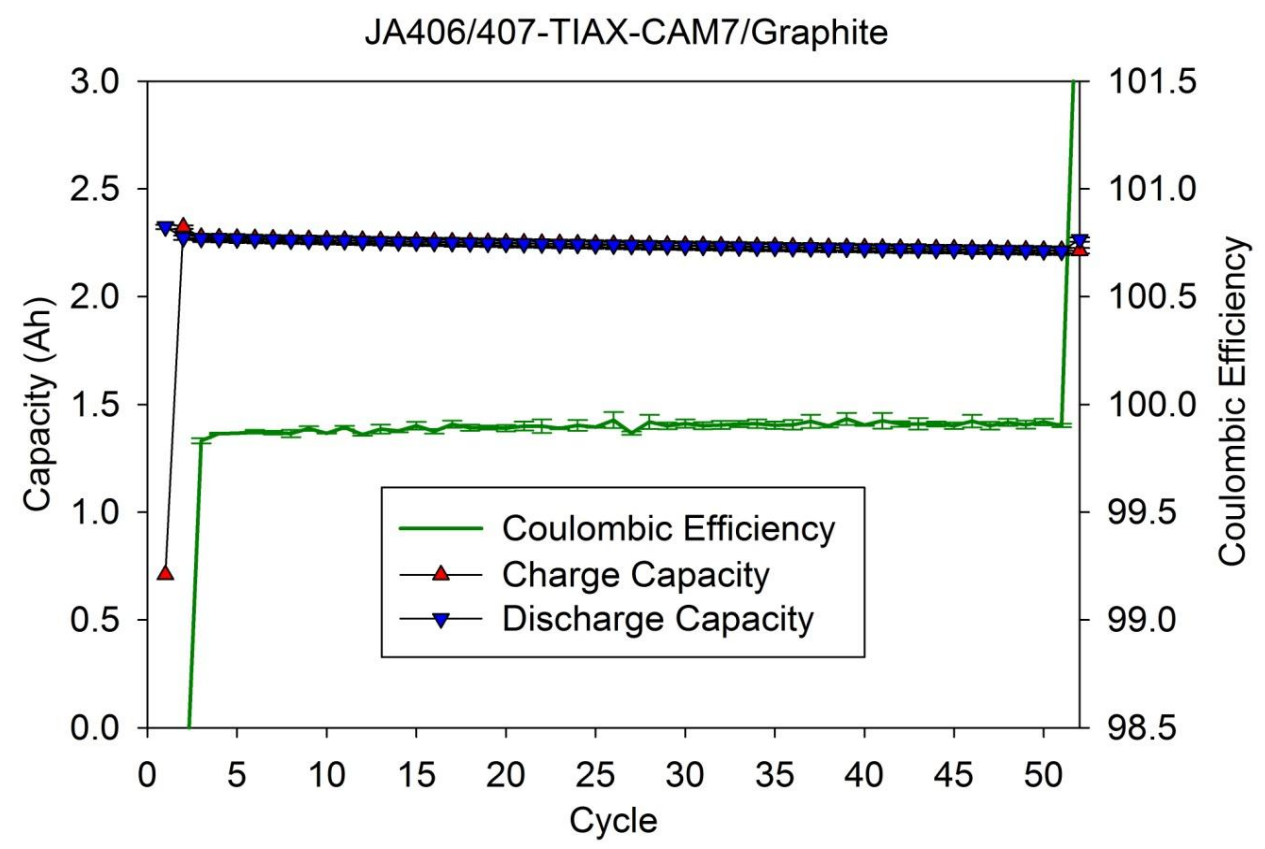

Fig. 8 High temperature $\left(50{ }^{\circ} \mathrm{C}\right)$ cycle life testing $(2.7-4.1 \mathrm{~V}$; Charge: $\mathrm{C} / 5 \mathrm{CC}, \mathrm{CV}$ to $\mathrm{C} / 20$; Discharge: $\mathrm{C} / 10$ for $1^{\text {st }}$ and $52^{\text {nd }}$ cycle, $\mathrm{C} / 2$ for $2^{\text {nd }}-51^{\text {st }}$ cycle) of high energy cells

\section{Conclusions}

Five sets of duplicate cells were provided by TIAX LLC for evaluation at high and low temperatures as part of the requirements set forth in the Phase II SBIR contract. The cells consisted of two sets of standard-loading cells and three sets of high-loading cells. The standardloading cells cycled well at room temperature with a fade rate of only $0.025 \%$ per cycle and a $\mathrm{C} / 20$ capacity and specific energy of $2.21 \mathrm{~A} \cdot \mathrm{h}$ and $203 \mathrm{~W} \cdot \mathrm{h} / \mathrm{kg}$, respectively. The low fade rate suggests the standard-loading cells are capable of up to 800 cycles while maintaining $80 \%$ of the initial capacity. Although the $\mathrm{C} / 20$ capacity of the cells at $-20{ }^{\circ} \mathrm{C}$ was reduced by only $18 \%$ $(1.81 \mathrm{~A} \cdot \mathrm{h})$, the slower ionic conductivity had a more dramatic effect at higher rates, reducing the $\mathrm{C} / 5$ capacity from $2.09 \mathrm{~A} \cdot \mathrm{h}$ at room temperature to $1.65 \mathrm{~A} \cdot \mathrm{h}$ at $-20{ }^{\circ} \mathrm{C}$ (a $21 \%$ reduction).

The high temperature cycle life of the standard-loading cells faded more dramatically, as expected, due to increased electrolyte oxidation and/or structural changes within the cathode/anode. With an initial capacity of $1.98 \mathrm{~A} \cdot \mathrm{h}$ and a fade rate of $0.048 \%$ per cycle, the high temperature cells are still project to be able to cycle $\sim 400$ cycles while maintaining $80 \%$ capacity retention. The ability of the standard-loading electrodes to cycle at low temperature, as well as the impressive cycle life at room temperature and high temperatures, marks an improvement over the state-of-the-art Li-ion battery. 
In order to improve the specific energy of the cells, TIAX LLC provided three sets of cells containing higher-loading electrodes. Although these cells do have a significantly higher specific energy ( $240 \mathrm{~W} \cdot \mathrm{h} / \mathrm{kg}$ vs. $203 \mathrm{~W} \cdot \mathrm{h} / \mathrm{kg}$ for standard-loading), the rate performance and cycle life of the cells suffer. A summary of the room temperature and low temperature discharge capacity and specific energy is shown in Table 3. The capacity of the standard-loading electrodes decreased from $2.23 \mathrm{~A} \cdot \mathrm{h}(\mathrm{C} / 20)$ to $2.12 \mathrm{~A} \cdot \mathrm{h}(\mathrm{C} / 5)$, a decrease of $\sim 4.9 \%$, while the higher-loading electrodes decreased from $2.67 \mathrm{~A} \cdot \mathrm{h}(\mathrm{C} / 20)$ to $2.51 \mathrm{~A} \cdot \mathrm{h}(\mathrm{C} / 5)$, a decrease of $6.0 \%$. Furthermore, the low temperature performance of the high-loading cells is worse due to the compounding effects of the decreased electrode conductivity, higher current density through the separator, and reduced ionic mobility through the higher-loading electrodes. The capacity of the higher-loading cells decreased from $2.67 \mathrm{~A} \cdot \mathrm{h}(\mathrm{RT})$ to $2.14 \mathrm{~A} \cdot \mathrm{h}$ (at $-20^{\circ} \mathrm{C}$ ) for $\mathrm{C} / 20$, a decrease of $20 \%$, and from $2.51 \mathrm{~A} \cdot \mathrm{h}(\mathrm{RT})$ to $1.72 \mathrm{~A} \cdot \mathrm{h}\left(\right.$ at $-20^{\circ} \mathrm{C}$ ) for $\mathrm{C} / 5$, a decrease of $31 \%$. Comparing the standardloading ( $20 \% \mathrm{C} / 5$ capacity decrease) and higher-loading (31\% C/5 capacity decrease) cell designs, there is a more significant decrease in capacity due to the operation at low temperature with higher-loading electrodes. It is notable that even with the larger relative capacity decrease of the higher-loading cell compared with the standard-loading cell; the capacity of the cell is still larger at $1.72 \mathrm{~A} \cdot \mathrm{h}$ versus $1.66 \mathrm{~A} \cdot \mathrm{h}$ for the standard-loading cells (at $\mathrm{C} / 5$ discharge). Thus, any decrease in rate performance is more than offset by benefits in overall specific energy.

The room temperature and high temperature cycle life tests for the high-loading cells display an initial $(\mathrm{C} / 2)$ capacity of 2.40 and $2.34 \mathrm{~A} \cdot \mathrm{h}$, respectively. The fade rates of the cells were $0.06 \%$ and $0.09 \%$ per cycle for the room temperature and high temperature cells, respectively. With the initial capacity and fade rates listed previously, the cycle life of the cells were calculated to be $\sim 350$ and $\sim 250$ cycles for the room temperature and high temperature, respectively, while still maintaining an $80 \%$ capacity retention.

The CAM-7/graphite cells provided by TIAX LLC demonstrate standard- and higher-loading electrode designs that could meet the needs of different military applications. The standardloading electrode cell designs display a lower specific energy than the higher-loading designs, but have a lower fade rate that enables a significantly longer cycle life (up to 800 cycles with $80 \%$ capacity retention). These cells are ideal for applications where cycle life is imperative, even in extreme conditions. The higher-loading cell designs, in contrast, provide a specific energy of up to $240 \mathrm{~W} \cdot \mathrm{h} / \mathrm{kg}$ (at C/20 discharge rate) and also display an improved low and high temperature capacity. The higher-loading cells, however, suffer from an increased fade rate that limits their projected cycle life to $\sim 350$ and $\sim 250$ cycles (for RT and $50{ }^{\circ} \mathrm{C}$ ) while maintaining $80 \%$ capacity retention. These cells are ideal for high energy applications (even in extreme conditions) where cycle life is a secondary concern. The CAM-7/graphite system is well suited for low and high temperature applications and offers many benefits over the state-of-the-art Liion battery cells. 


\section{List of Symbols, Abbreviations, and Acronyms}

\begin{tabular}{|c|c|}
\hline EVs & electric vehicles \\
\hline HEVs & hybrid electric vehicles \\
\hline HT & high temperature \\
\hline $\mathrm{Li}$ & lithium \\
\hline $\mathrm{LiCoO}_{2}$ or $\mathrm{LCO}$ & lithium cobalt oxide \\
\hline $\mathrm{LiCoPO}_{4}$ or $\mathrm{LCP}$ & lithium cobalt phosphate \\
\hline $\mathrm{LiFePO}_{4}$ or $\mathrm{LFP}$ & lithium iron phosphate \\
\hline $\mathrm{LiMn}_{2} \mathrm{O}_{4}$ or LMO & lithium manganese oxide \\
\hline $\mathrm{LiNiO}_{2}$ or $\mathrm{LNO}$ & lithium nickel oxide \\
\hline $\mathrm{LiNi}_{0.5} \mathrm{M}_{1.5} \mathrm{O}_{4}$ or LNMO & lithium nickel manganese oxide \\
\hline $\mathrm{LiNi}_{\mathrm{x}} \mathrm{Co}_{\mathrm{y}} \mathrm{Mn}_{\mathrm{z}} \mathrm{O}_{2}$ or $\mathrm{NCM}$ & lithium nickel cobalt manganese oxide \\
\hline $\mathrm{LiNi}_{\mathrm{x}} \mathrm{Co}_{\mathrm{y}} \mathrm{Al}_{\mathrm{z}} \mathrm{O}_{2}$ or NCA & lithium nickel cobalt aluminum oxide \\
\hline LT & low temperature \\
\hline PHEVs & plug-in hybrid electric vehicles \\
\hline RT & room temperature \\
\hline SBIR & Small Business Innovation Research \\
\hline
\end{tabular}




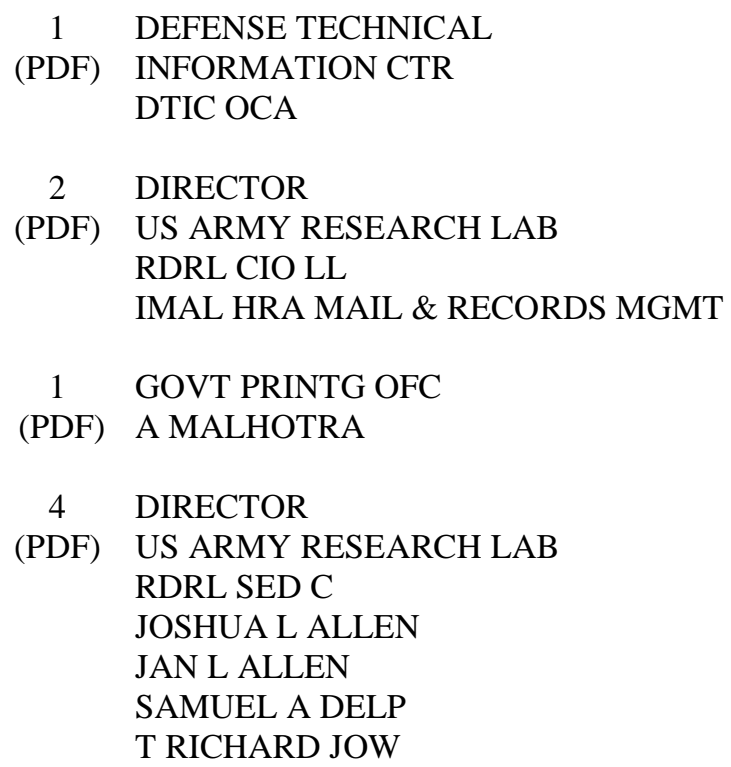


INTENTIONALLY LEFT BLANK. 